\title{
Clinical Significance of Prognostic Nutritional Index in the Treatment of Esophageal Squamous Cell Carcinoma
}

\author{
KOJI TAKAO, HIROTAKA KONISHI, HITOSHI FUJIWARA, ATSUSHI SHIOZAKI, KATSUTOSHI SHODA, \\ TOSHIYUKI KOSUGA, TAKESHI KUBOTA, TOMOHIRO ARITA, RYO MORIMURA, YASUTOSHI MURAYAMA, \\ YOSHIAKI KURIU, HISASHI IKOMA, MASAYOSHI NAKANISHI, KAZUMA OKAMOTO and EIGO OTSUJI \\ Division of Digestive Surgery, Department of Surgery, Kyoto Prefectural University of Medicine, Kyoto, Japan
}

\begin{abstract}
Background/Aim: The prognostic nutritional index (PNI) is reported to affect postoperative complications and survival of patients with esophageal squamous cell carcinoma (ESCC). The aim of this study is to investigate the clinical significance of PNI in treatment of ESCC. Patients and Methods: Two hundred and sixtythree patients who underwent radical esophagectomy were retrospectively analyzed. PNI was calculated in the pretreatment (pre-Tx), post-neoadjuvant chemotherapy (post-NAC), and postoperative periods. Results: Pre-Tx $P N I$ positively correlated with prognosis irrespective of undergoing NAC $(p<0.05)$. In the patients with NAC, preTx PNI was one of the independent prognostic factors $(p=0.04)$. In patients with low pre-Tx PNI, the prognosis was improved by increase of PNI after NAC $(p=0.08)$, and two cycles of NAC significantly correlated with high postNAC PNI (p=0.04). Conclusion: Pre-Tx PNI is an independent prognostic factor irrespective of NAC. Patients in whom the post-NAC PNI can be improved have a high probability of obtaining a good prognosis.
\end{abstract}

Esophageal cancer (EC) is the seventh most common cancer worldwide, and the sixth most common cause of cancer death (1). It is one of the most aggressive malignancies. Early detection and multimodality treatment, which consists of surgery combined with chemotherapy/radiotherapy, may most likely help attain long-term survival $(2,3)$. In Western

This article is freely accessible online.

Correspondence to: Hirotaka Konishi, MD, Ph.D., Division of Digestive Surgery, Department of Surgery, Kyoto Prefectural University of Medicine, 465 Kajii-cho, Kamigyo-ku, 6028566, Kyoto, Japan. Tel: +81 752515527, Fax: +81 752515522, e-mail: h-koni7@koto.kpu-m.ac.jp

Key Words: Prognostic nutritional index, esophageal squamous cell carcinoma, neoadjuvant chemotherapy, esophagectomy, prognosis. countries, neoadjuvant chemoradiotherapy has been commonly applied for treating resectable advanced EC (4). In Japan, neoadjuvant chemotherapy (NAC) using 5fluorouracil plus cisplatin (FP) has been recommended as the standard treatment for clinical stage (cStage) II and III esophageal squamous cell carcinoma (ESCC) according to the JCOG9907 study (5). Recently, highly intensive regimens (e.g. combination chemotherapy consisting of docetaxel, cisplatin, and 5-fluorouracil) have been applied in a NAC setting $(6,7)$.

NAC may have beneficial effects of reducing the tumor bulk and micrometastasis preoperatively but such intensive chemotherapy can also lead to deterioration of the patient's nutritional status due to adverse effects $(8,9)$. A poor nutritional status is one of the most important problems faced by patients with cancer (10). A poor preoperative nutritional status is associated with postoperative complications, inhospital mortality, prolonged hospital stay, and poor prognosis in patients with gastrointestinal cancer (11-14).

The prognostic nutritional index (PNI) is calculated using the serum albumin level and total lymphocyte count in the peripheral blood and has been used as a nutritional and immunological indicator (15). Although PNI was originally a predictor of postoperative complications in patients with gastrointestinal cancer (15), it has been recently recognized as an independent predictor of long-term survival for various cancer types, including EC (16-20). However, the significance of PNI as a predictor of NAC effectiveness, or a prognostic factor of patients with EC who underwent NAC has been poorly investigated. In the present study, we evaluated the clinical significance of PNI in patients with ESCC who underwent radical esophagectomy with or without NAC.

\section{Patients and Methods}

Patient characteristics and clinical evaluation. We retrospectively reviewed a database containing the clinicopathological and prognostic data of 263 patients who were histologically diagnosed 
Table I. Background of patients with esophageal squamous cell carcinoma (ESCC)

\begin{tabular}{|c|c|c|c|}
\hline \multirow[t]{2}{*}{ Characteristic } & \multicolumn{3}{|c|}{$\operatorname{ESCC}(n=263)$} \\
\hline & $\begin{array}{l}\text { No NAC } \\
(\mathrm{n}=98)\end{array}$ & $\begin{array}{c}\text { NAC } \\
(n=165)\end{array}$ & $p$-Value \\
\hline \multicolumn{4}{|l|}{ Age } \\
\hline Median (range) & $67.5(48-88)$ & $66(34-83)$ & 0.02 \\
\hline \multicolumn{4}{|l|}{ Gender } \\
\hline Female & 11 & 35 & 0.03 \\
\hline Male & 87 & 130 & \\
\hline \multicolumn{4}{|l|}{ BMI, $\mathrm{kg} / \mathrm{m}^{2}$} \\
\hline Mean \pm SD & $21.6 \pm 3.0$ & $20.7 \pm 3.4$ & 0.034 \\
\hline \multicolumn{4}{|c|}{ Pre-Tx albumin level (g/dl) } \\
\hline Mean \pm SD & $4.2 \pm 0.4$ & $4.1 \pm 0.4$ & 0.08 \\
\hline \multicolumn{4}{|c|}{ Pre-Tx lymphocyte count $(/ \mu \mathrm{l})$} \\
\hline Mean \pm SD & $1650 \pm 628$ & $1862 \pm 651$ & 0.01 \\
\hline \multicolumn{4}{|l|}{ Pre-Tx PNI } \\
\hline Mean \pm SD & $50.4 \pm 5.3$ & $50.6 \pm 4.8$ & 0.75 \\
\hline \multicolumn{4}{|l|}{ Post-NAC PNI } \\
\hline Mean \pm SD & - & $46.9 \pm 5.8$ & - \\
\hline \multicolumn{4}{|l|}{ Postoperative PNI } \\
\hline Mean \pm SD & $43.6 \pm 6.6$ & $43.6 \pm 6.7$ & 0.96 \\
\hline \multicolumn{4}{|l|}{ Location } \\
\hline $\mathrm{Ce}$ & 4 & 12 & 0.62 \\
\hline $\mathrm{Ut}$ & 12 & 25 & \\
\hline Mt & 54 & 77 & \\
\hline $\mathrm{Lt}$ & 25 & 47 & \\
\hline $\mathrm{Ae}$ & 3 & 4 & \\
\hline \multicolumn{4}{|l|}{ Tumor size, mm } \\
\hline Mean \pm SD & $41.8 \pm 28.1$ & $44.4 \pm 29.4$ & 0.49 \\
\hline \multicolumn{4}{|l|}{ cT Factor } \\
\hline $\mathrm{T} 1$ & 71 & 10 & $<0.001$ \\
\hline $\mathrm{T} 2$ & 7 & 26 & \\
\hline $\mathrm{T} 3$ & 20 & 114 & \\
\hline $\mathrm{T} 4$ & 0 & 15 & \\
\hline \multicolumn{4}{|l|}{ cN Factor } \\
\hline No & 74 & 42 & $<0.001$ \\
\hline N1 & 10 & 47 & \\
\hline $\mathrm{N} 2$ & 10 & 57 & \\
\hline N3 & 2 & 12 & \\
\hline N4 & 2 & 7 & \\
\hline \multicolumn{4}{|l|}{ cStage } \\
\hline 0 & 13 & 0 & $<0.001$ \\
\hline I & 53 & 1 & \\
\hline II & 14 & 55 & \\
\hline III & 16 & 88 & \\
\hline IV & 2 & 21 & \\
\hline
\end{tabular}

ESCC, Esophageal squamous cell carcinoma; NAC, neoadjuvant chemotherapy; BMI, body mass index; Pre-Tx, pretreatment; Post-NAC, post-neoadjuvant chemotherapy; PNI, prognostic nutritional index.

with ESCC between January 2008 and December 2014 and who underwent radical esophagectomy. The median length of the followup period for censored cases was 53.6 months (range $=1-119$ months).

Before initiating the NAC, clinical characteristics were evaluated through upper gastrointestinal endoscopy, computed
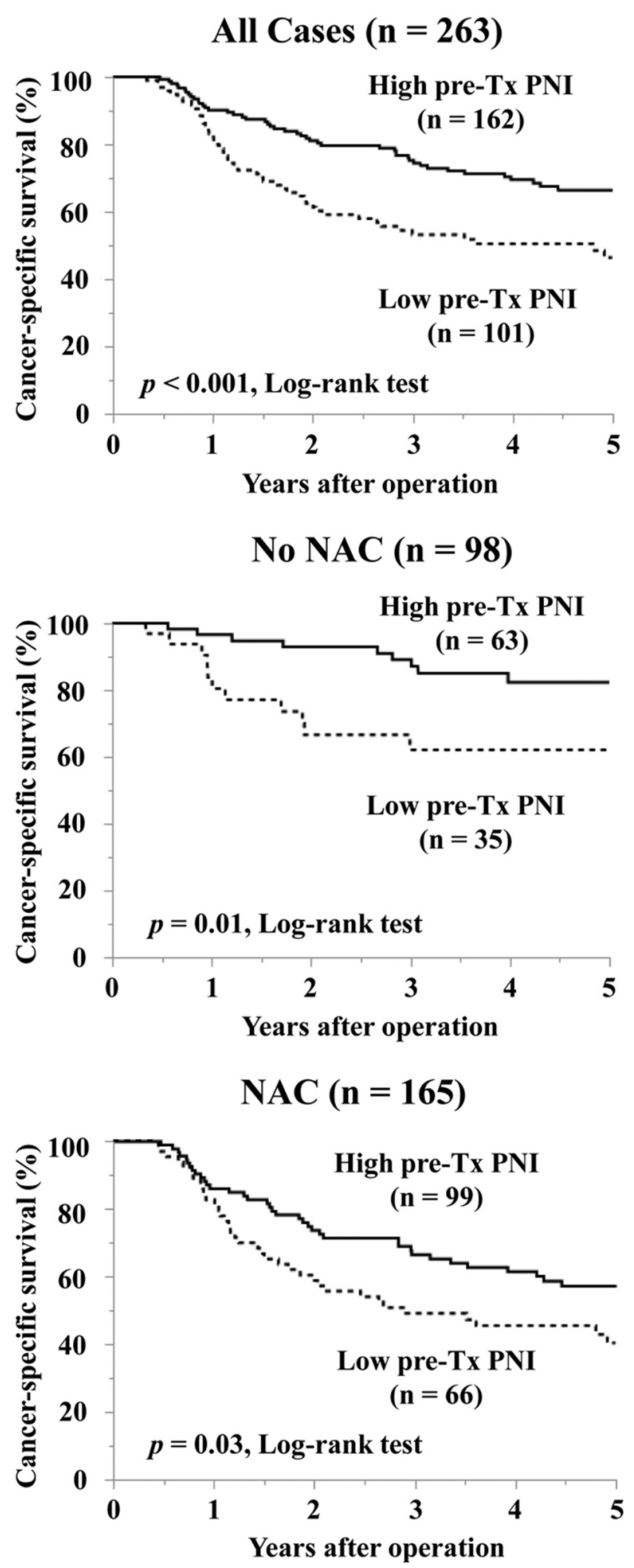

Figure 1. Cancer-specific survival in relation to pretreatment prognostic nutritional index (PNI) status examined using the Kaplan-Meier method in patients treated with and without neoadjuvant chemotherapy (NAC). Patients were divided into groups with high and low pretreatment PNI level using a cut-off value of 49 . 
Table II. Clinicopathological features in relation to pretreatment prognostic nutritional index (pre-Tx PNI) in patients treated with neoadjuvant chemotherapy (NAC).

\begin{tabular}{|c|c|c|c|c|}
\hline \multirow[b]{2}{*}{ Variable } & \multirow[b]{2}{*}{$\begin{array}{l}\text { Total patients } \\
\quad(\mathrm{n}=165)\end{array}$} & \multicolumn{2}{|c|}{ Pre-Tx PNI } & \multirow[b]{2}{*}{$p$-Value } \\
\hline & & $\begin{array}{l}\text { High } \\
(\mathrm{n}=99)\end{array}$ & $\begin{array}{l}\text { Low } \\
(\mathrm{n}=66)\end{array}$ & \\
\hline \multicolumn{5}{|l|}{ Age } \\
\hline$\geq 66$ Years & 87 & $51(52 \%)$ & $36(55 \%)$ & \multirow[t]{2}{*}{0.7} \\
\hline$<66$ Years & 78 & $48(48 \%)$ & $30(45 \%)$ & \\
\hline \multicolumn{5}{|l|}{ Gender } \\
\hline Female & 35 & $21(21 \%)$ & $14(21 \%)$ & \multirow[t]{2}{*}{1} \\
\hline Male & 130 & $78(79 \%)$ & $52(79 \%)$ & \\
\hline \multicolumn{5}{|l|}{ Post-NAC PNI } \\
\hline$\geq 46$ & 94 & $68(69 \%)$ & $26(39 \%)$ & \multirow[t]{2}{*}{$<0.001$} \\
\hline$<46$ & 71 & $31(31 \%)$ & $40(61 \%)$ & \\
\hline \multicolumn{5}{|c|}{ Postoperative PNI } \\
\hline$\geq 43$ & 86 & $54(55 \%)$ & $32(48 \%)$ & \multirow[t]{2}{*}{0.45} \\
\hline$<43$ & 79 & $45(45 \%)$ & $34(52 \%)$ & \\
\hline \multicolumn{5}{|l|}{ Tumor size } \\
\hline$\geq 40 \mathrm{~mm}$ & 88 & $53(54 \%)$ & $35(53 \%)$ & \multirow[t]{2}{*}{0.95} \\
\hline$<40 \mathrm{~mm}$ & 77 & $46(46 \%)$ & $31(47 \%)$ & \\
\hline \multicolumn{5}{|l|}{ cT Factor } \\
\hline $\mathrm{T} 1-2$ & 36 & $23(3 \%)$ & $13(20 \%)$ & \multirow{2}{*}{0.59} \\
\hline T3-4 & 129 & $76(77 \%)$ & $53(80 \%)$ & \\
\hline \multicolumn{5}{|l|}{$\mathrm{cN}$ Factor } \\
\hline N0 & 42 & $30(30 \%)$ & $12(18 \%)$ & \multirow[t]{2}{*}{0.08} \\
\hline $\mathrm{N} 1-4$ & 123 & $69(70 \%)$ & $54(82 \%)$ & \\
\hline \multicolumn{5}{|l|}{ cStage } \\
\hline $\mathrm{I}-\mathrm{II}$ & 56 & $39(39 \%)$ & $17(26 \%)$ & \multirow[t]{2}{*}{0.07} \\
\hline III-IV & 109 & $60(61 \%)$ & $49(74 \%)$ & \\
\hline \multicolumn{5}{|c|}{ Clinical response } \\
\hline $\mathrm{CR} / \mathrm{PR}$ & 66 & $33(33 \%)$ & $33(50 \%)$ & \multirow[t]{2}{*}{0.03} \\
\hline $\mathrm{SD} / \mathrm{PD}$ & 99 & $66(67 \%)$ & $33(50 \%)$ & \\
\hline \multicolumn{5}{|c|}{ Histological response } \\
\hline Grade 0-Ia & 109 & $66(67 \%)$ & $43(65 \%)$ & \multirow{2}{*}{0.84} \\
\hline Grade Ib-III & 56 & $33(33 \%)$ & $23(35 \%)$ & \\
\hline \multicolumn{5}{|c|}{ Postoperative complications } \\
\hline Grade 0-II & 128 & $78(79 \%)$ & $50(76 \%)$ & \multirow[t]{2}{*}{0.65} \\
\hline Grade III-IV & 37 & $21(21 \%)$ & $16(24 \%)$ & \\
\hline Adverse events & & & & \\
\hline Grade 0-2 & 93 & $61(62 \%)$ & $32(48 \%)$ & 0.1 \\
\hline Grade 3-4 & 72 & $38(38 \%)$ & $34(52 \%)$ & \\
\hline Cycles of NAC & & & & \\
\hline 1 & 21 & $12(12 \%)$ & $9(14 \%)$ & 0.78 \\
\hline 2 & 144 & $87(88 \%)$ & $57(86 \%)$ & \\
\hline
\end{tabular}

Pre-Tx, Pretreatment; PNI, prognostic nutritional index; NAC, neoadjuvant chemotherapy; Post-NAC, post-neoadjuvant chemotherapy; $\mathrm{CR}$, complete response; PR, partial response; SD, stable disease; PD, progressive disease.

tomography, and esophagography. The upper gastrointestinal endoscopy and computed tomography were also performed after every cycle of NAC to evaluate the clinical response to chemotherapy. Blood test data were examined before every NAC course and the operation. In order to detect recurrent lesions, the patient was followed-up for at least approximately 5 years postoperatively at an Outpatient Clinic.
Table III. Prognostic factors for patients treated with neoadjuvant chemotherapy (NAC).

\begin{tabular}{|c|c|c|c|c|c|c|}
\hline \multirow[b]{2}{*}{ Variable } & \multirow{2}{*}{$\begin{array}{c}\text { Total } \\
\text { patients } \\
(\mathrm{n}=165)\end{array}$} & \multirow{2}{*}{$\begin{array}{c}\text { 5-Year } \\
\text { CSS } \\
(\%)\end{array}$} & \multirow{2}{*}{$\frac{\text { Univariate }}{p \text {-Value }}$} & \multicolumn{3}{|c|}{ Multivariate } \\
\hline & & & & HR & $95 \% \mathrm{CI}$ & $p$-Value \\
\hline \multicolumn{7}{|l|}{ Pre-Tx PNI } \\
\hline$\geq 49$ & 99 & 62.6 & 0.03 & 1 & & \\
\hline$<49$ & 66 & 45.5 & & 1.64 & $1.03-2.61$ & 0.04 \\
\hline \multicolumn{7}{|l|}{ Post-NAC PNI } \\
\hline$\geq 46$ & 94 & 60.6 & 0.15 & - & - & - \\
\hline$<46$ & 71 & 49.3 & & & & \\
\hline \multicolumn{7}{|c|}{ Postoperative PNI } \\
\hline$\geq 43$ & 86 & 51.2 & 0.21 & - & - & - \\
\hline$<43$ & 79 & 60.8 & & & & \\
\hline \multicolumn{7}{|l|}{$\begin{array}{l}\text { Tumor size } \\
(\mathrm{mm})\end{array}$} \\
\hline$\geq 40 \mathrm{~mm}$ & 88 & 47.7 & 0.03 & 1.48 & $0.91-2.45$ & 0.11 \\
\hline$<40 \mathrm{~mm}$ & 77 & 64.9 & & 1 & & \\
\hline \multicolumn{7}{|l|}{$\mathrm{cT}$ factor } \\
\hline $\mathrm{T} 1-2$ & 36 & 66.7 & 0.13 & - & - & - \\
\hline T3-4 & 129 & 52.7 & & & & \\
\hline \multicolumn{7}{|l|}{$\mathrm{cN}$ factor } \\
\hline No & 42 & 66.7 & 0.1 & - & - & - \\
\hline N1-4 & 123 & 52 & & & & \\
\hline \multicolumn{7}{|l|}{ cStage } \\
\hline I-II & 56 & 71.4 & 0.003 & 1 & & \\
\hline III-IV & 109 & 47.7 & & 1.95 & $1.13-3.54$ & 0.02 \\
\hline \multicolumn{7}{|c|}{ Clinical response } \\
\hline $\mathrm{CR} / \mathrm{PR}$ & 66 & 56.1 & 0.95 & - & - & - \\
\hline $\mathrm{SD} / \mathrm{PD}$ & 99 & 55.6 & & & & \\
\hline \multicolumn{7}{|c|}{ Histological response } \\
\hline Grade 0-Ia & 109 & 48.6 & 0.009 & 2.07 & $1.21-3.72$ & 0.007 \\
\hline Grade Ib-III & 56 & 69.6 & & 1 & & \\
\hline \multicolumn{7}{|l|}{ Adverse events } \\
\hline Grade $0-2$ & 93 & 60.2 & 0.19 & - & - & - \\
\hline Grade 3-4 & 72 & 50 & & & & \\
\hline \multicolumn{7}{|l|}{ Cycles of NAC } \\
\hline 1 & 21 & 42.9 & 0.2 & - & - & - \\
\hline 2 & 144 & 57.6 & & & & \\
\hline
\end{tabular}

NAC, Neoadjuvant chemotherapy; CSS, cancer-specific survival; HR, hazard ratio; CI, confidence interval; Pre-Tx, pretreatment; PNI, prognostic nutritional index; Post-NAC, post-neoadjuvant chemotherapy; $\mathrm{CR}$, complete response; PR, partial response; SD, stable disease; PD, progressive disease.

The clinical and histological responses to NAC were evaluated according to the 11th edition of the Japanese Classification of Esophageal Cancer published in 2017 (21). The severities of postoperative complication were defined according to the ClavienDindo classification, version 2.0 (22). Furthermore, adverse events due to chemotherapy were evaluated according to the Common Terminology Criteria for Adverse Events version 5.0 (23).

Determination of PNI and the cut-off value. The serum albumin level and total lymphocyte count were examined in the pre-Tx, post$\mathrm{NAC}$, and postoperative periods. PNI was calculated as follows: $10 \times$ serum albumin $(\mathrm{g} / \mathrm{dl})+0.005 \times$ total lymphocyte count $\left(/ \mathrm{mm}^{3}\right)$ 


\section{A}

High pre-Tx PNI (n = 99)

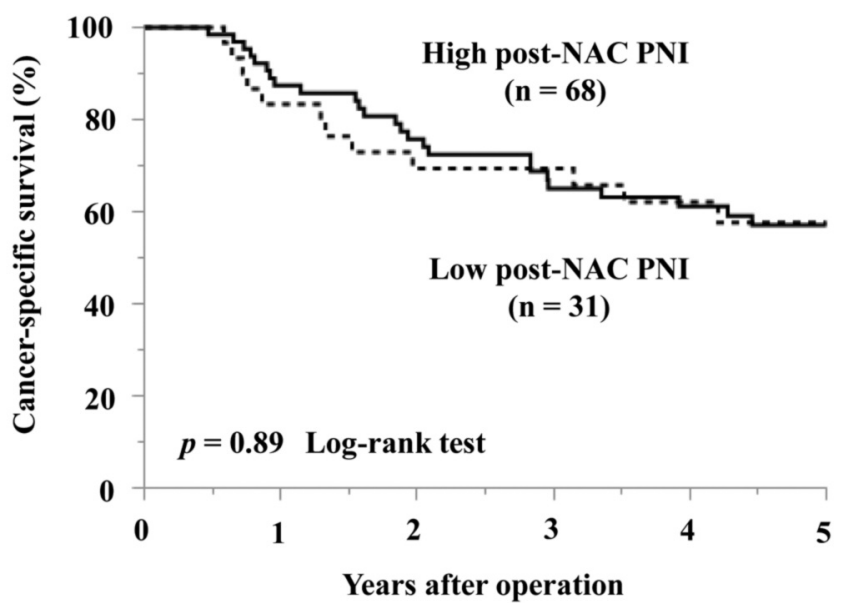

B Low pre-Tx PNI $(n=66)$

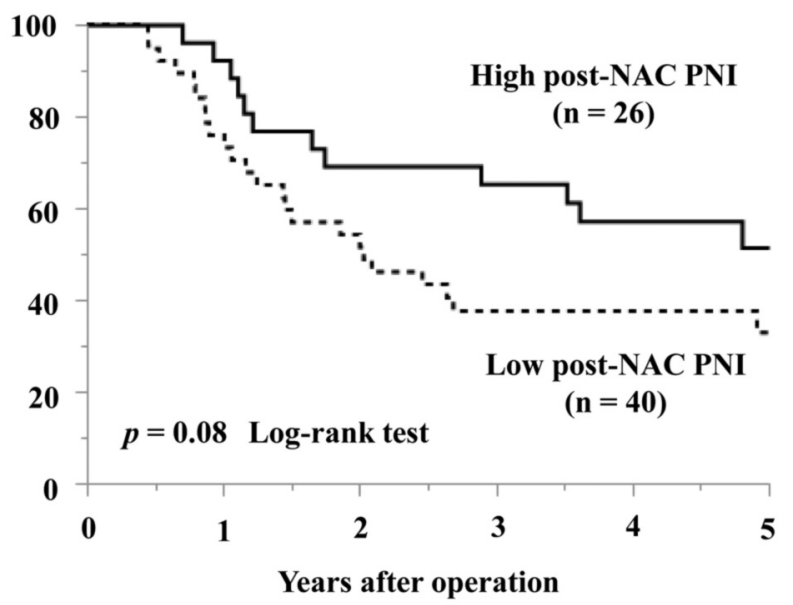

Figure 2. Cancer-specific survival of patients with high (A) and low (B) pretreatment (pTx) prognostic nutritional index (PNI) treated with neoadjuvant chemotherapy (NAC) is shown according to the post-NAC PNI, using a cut-off value of 46.

(15). The cut-off values of PNI in each period were determined as 49,46 , and 43 , respectively, by analysis of the receiver operating characteristics curve using the PNI value and prognostic data. Patients were divided into two groups, namely high PNI and low PNI, using these cut-off values.

Treatment courses. Most of the NAC procedures were performed with the FP regimen according to JCOG 9907 (5). In the FP regimen, $80 \mathrm{mg} / \mathrm{m}^{2}$ of cisplatin was administered on day 1 , and 800 $\mathrm{mg} / \mathrm{m}^{2}$ of 5 -fluorouracil was administered from day 1 to day 5 (24). Two courses of this regimen were conducted every 3 weeks. The docetaxel, cisplatin, and 5-fluorouracil regimen was provided for some patients who were clinically diagnosed with lymph node metastasis. A total of 144 patients completed the two courses of neoadjuvant FP therapy, and 21 other patients underwent only one course of NAC due to adverse events or inadequate tumor control. All patients underwent radical esophagectomy with two or three fields of lymph node dissection; 56 patients underwent three-field lymph node dissection (21.3\%). The reconstruction was generally performed using gastric tube via retrosternal route. Ileocolic or posterior mediastinal route reconstruction was sometimes performed in accordance with the patient's condition.

Statistical analysis. Categorical variables are presented as numbers and percentages, and the groups were compared using the chi-square test or Fisher's exact test. Continuous variables are shown as the average and range, and the averages were compared using the $t$-test. Cancerspecific survival was measured from surgery for EC. Survival curves were estimated using the Kaplan-Meier method, and the differences were calculated using the log-rank test. Multivariate analysis was performed using the Cox proportional hazard model. Furthermore, all statistical analyses were performed using the statistical software JMP (version 13 for Windows, SAS Institute, Cary, NC, USA), and a value of $p<0.05$ was considered statistically significant.

\section{Results}

Patient background and PNI value. The clinicopathological features of all patients are summarized in Table I. Among the 263 patients, 165 received NAC, and this was significantly associated with advanced disease. The pre-Tx albumin level and lymphocyte count were significantly different between patients treated with and without NAC ( $p=0.01$ and $p=0.004$, respectively). However, the mean pre-Tx PNI values of 50.6 and 50.4 in patients with and without NAC were not significantly different between two groups $(p=0.73)$. Similarly, the postoperative PNI values were not different $(p=0.95)$.

Survival analysis in relation to pre-Tx PNI. Figure 1 indicates the results of the survival analysis in relation to pre-Tx PNI. The prognosis of patients with low pre-Tx PNI was significantly worse than that of those with high pre-Tx PNI considering the whole patient cohort $(p<0.001)$. Moreover, this pattern was similar for patients treated with and without NAC ( $p=0.01$ and $p=0.03$, respectively).

Relationship between the pre-Tx PNI value and clinicopathological features in patients treated with NAC. Table II presents the clinicopathological features in relation to the pre-Tx PNI level in patients treated with NAC. PostNAC PNI and clinical response were significantly positively associated with the pre-Tx PNI level $(p<0.001$ and $p=0.03$, respectively). Clinical $\mathrm{N}$ factor $(p=0.08)$, cStage $(p=0.07)$, and adverse events $(p=0.10)$ were not significantly related to the pre-Tx PNI level. In addition, the pre-Tx PNI did not 
correlate with the occurrence of postoperative complications and the effects or adverse events of NAC.

Prognostic factors of patients treated with NAC. In the univariate analysis, the pre-Tx PNI $(p=0.03)$, tumor size $(p=0.03)$, cStage $(p=0.003)$, and histological response $(p=0.009)$ were found to be prognostic factors (Table III). In the multivariate analysis, the pre-Tx PNI $(\mathrm{HR}=1.64,95 \% \mathrm{CI}=1.03-2.61 ; p=0.04)$, cStage $(\mathrm{HR}=1.95,95 \% \mathrm{CI}=1.13-3.54 ; p=0.02)$, and histological response $(\mathrm{HR}=2.07,95 \% \mathrm{CI}=1.21-3.72 ; p=0.007)$ were independent prognostic factors in patients with NAC.

Subgroup analysis of survival according to post-NAC PNI level. In patients with high pre-Tx PNI, no significant difference was observed in survival between the groups with high and low post-NAC PNI ( $p=0.89$, Figure $2 \mathrm{~A})$. However, in patients with low pre-Tx PNI, high post-NAC PNI was related to a better prognosis than low post-NAC PNI ( $p=0.08$, Figure $2 \mathrm{~B})$. Furthermore, high post-NAC PNI was significantly associated with the completion of two planned cycles of NAC ( $p=0.04$, Table IV).

\section{Discussion}

The prognostic value of PNI in patients with EC has been extensively investigated $(11,16)$. For instance, Feng and Chen demonstrated that the preoperative PNI is an independent predictor of cancer-specific survival in patients with EC (16). In another study, PNI correlated with the depth of tumor invasion, lymph node metastasis, and tumor stage in patients with gastric and colorectal cancer $(17,19)$. However, as far as we are aware, no article exists that examined the relationship between prognosis and PNI in each treatment course, including NAC. Herein, we found that the prognosis of patients with high pre-Tx PNI was significantly better irrespective of whether they underwent NAC, and the pre-Tx PNI was an independent prognostic factor in patients treated with NAC. Thus, preoperative nutritional status and immunity may be associated with the therapeutic effectiveness of NAC or the prognosis of advanced cancer. Low nutritional status and immunity to cancer cells may promote the proliferation of bloodcirculating tumor cells (18), and PNI reflects the extent of tumor progression $(16,19,25)$. However, in the present study, the relationship between pre-Tx PNI and the therapeutic effectiveness of NAC was not confirmed.

Chemotherapy can paradoxically cause both deterioration and improvement of the nutritional status due to toxicities and overall tumor reduction (26). Nutritional parameters, such as the body mass index, serum albumin, and hemoglobin following chemotherapy or chemoradiotherapy are significantly reduced in patients with EC $(24,27)$. Therefore, the differences of nutritional status immediately before
Table IV. Clinicopathological features in relation to prognostic nutritional index (PNI) post neoadjuvant chemotherapy (NAC) in patients with low pre-Tx PNI.

\begin{tabular}{|c|c|c|c|c|}
\hline \multirow[b]{2}{*}{ Variable } & \multirow[b]{2}{*}{$\begin{array}{l}\text { Total patients } \\
\quad(\mathrm{n}=66)\end{array}$} & \multicolumn{2}{|c|}{ Post-NAC PNI } & \multirow[b]{2}{*}{$p$-Value } \\
\hline & & $\begin{array}{l}\text { High } \\
(\mathrm{n}=26)\end{array}$ & $\begin{array}{l}\text { Low } \\
(\mathrm{n}=40)\end{array}$ & \\
\hline \multicolumn{5}{|l|}{ Age } \\
\hline$\geq 66$ Years & 36 & $12(46 \%)$ & $24(60 \%)$ & \multirow[t]{2}{*}{0.27} \\
\hline$<66$ Years & 30 & $14(54 \%)$ & $16(40 \%)$ & \\
\hline \multicolumn{5}{|l|}{ Gender } \\
\hline Female & 14 & $5(19 \%)$ & $9(23 \%)$ & \multirow[t]{2}{*}{0.75} \\
\hline Male & 52 & $21(81 \%)$ & $31(77 \%)$ & \\
\hline \multicolumn{5}{|l|}{ Postoperative PNI } \\
\hline$\geq 43$ & 32 & $14(54 \%)$ & $18(45 \%)$ & \multirow[t]{2}{*}{0.48} \\
\hline$<43$ & 34 & $12(46 \%)$ & $22(55 \%)$ & \\
\hline \multirow[t]{2}{*}{ Tumor size $(\mathrm{mm})$} & 35 & $14(54 \%)$ & $21(53 \%)$ & \multirow[t]{2}{*}{0.91} \\
\hline & 31 & $12(46 \%)$ & $19(47 \%)$ & \\
\hline \multicolumn{5}{|l|}{ cT Factor } \\
\hline $\mathrm{T} 1-2$ & 13 & $6(23 \%)$ & $7(18 \%)$ & \multirow[t]{2}{*}{0.58} \\
\hline T3-4 & 53 & $20(77 \%)$ & $33(82 \%)$ & \\
\hline \multicolumn{5}{|l|}{$\mathrm{cN}$ Factor } \\
\hline No & 12 & $7(27 \%)$ & $5(13 \%)$ & \multirow{2}{*}{0.14} \\
\hline N1-4 & 54 & $19(73 \%)$ & $35(87 \%)$ & \\
\hline \multicolumn{5}{|l|}{ cStage } \\
\hline $\mathrm{I}-\mathrm{II}$ & 17 & $9(35 \%)$ & $8(20 \%)$ & \multirow[t]{2}{*}{0.19} \\
\hline III-IV & 49 & $17(65 \%)$ & $32(80 \%)$ & \\
\hline \multicolumn{5}{|l|}{ Clinical response } \\
\hline $\mathrm{CR} / \mathrm{PR}$ & 33 & $14(54 \%)$ & $19(48 \%)$ & \multirow[t]{2}{*}{0.61} \\
\hline $\mathrm{PD} / \mathrm{SD}$ & 33 & $12(46 \%)$ & $21(52 \%)$ & \\
\hline \multicolumn{5}{|c|}{ Histological response } \\
\hline Grade 0-Ia & 43 & $15(58 \%)$ & $28(70 \%)$ & \multirow[t]{2}{*}{0.31} \\
\hline Grade Ib-III & 23 & $11(42 \%)$ & $12(30 \%)$ & \\
\hline \multicolumn{5}{|c|}{ Postoperative complications } \\
\hline Grade 0 -II & 50 & $22(85 \%)$ & $28(72 \%)$ & \multirow[t]{2}{*}{0.17} \\
\hline Grade III-V & 16 & $4(15 \%)$ & $12(28 \%)$ & \\
\hline \multicolumn{5}{|l|}{ Adverse events } \\
\hline Grade $0-2$ & 32 & $15(58 \%)$ & $17(43 \%)$ & \multirow[t]{2}{*}{0.23} \\
\hline Grade 3-4 & 34 & $11(42 \%)$ & $23(57 \%)$ & \\
\hline \multicolumn{5}{|l|}{ Cycles of NAC } \\
\hline 1 & 9 & $1(4 \%)$ & $8(20 \%)$ & \multirow[t]{2}{*}{0.04} \\
\hline 2 & 57 & $25(96 \%)$ & $32(80 \%)$ & \\
\hline
\end{tabular}

PNI, Prognostic nutritional index; NAC, neoadjuvant chemotherapy; Pre-Tx, pretreatment; Post-NAC, post-neoadjuvant chemotherapy; CR, complete response; PR, partial response; SD, stable disease; PD, progressive disease.

undergoing NAC and surgery may accurately predict the long-term survival of patients receiving NAC.

Patients with EC are often malnourished and difficult to optimize nutritionally. While evidence suggests that neoadjuvant therapy can offer a survival advantage, associated toxicity can exacerbate an already poor nutritional status. There is currently no accepted standard of care regarding the optimal nutritional approach. However, the effects of nutritional intervention for patients with EC have been evaluated (28-30). Fietkau et al. found that immunonutrition 
consisting of n-3 polyunsaturated fatty acids improved the nutritional score in patients with head and neck cancer treated with chemoradiotherapy (28). Cools-Lartigue et al. reported that dietary counseling under the supervision of a specialized nutritionist can effectively maintain the body mass index and serum albumin levels during NAC in patients with esophageal adenocarcinoma (29). In the systematic review of Huddy et $a l$, the optimal nutritional approach during NAC prior to the surgical resection of EC was unclear because of the limitation in case series, there being few prospective multicenter or comparative studies (30). In the present study, in the group with low pre-Tx PNI, the prognosis of patients with high postNAC PNI was improved compared with those with low postNAC PNI. The effects of nutritional intervention employed during NAC on long-term outcomes remain unexplored.

The present study has some limitations. This study is a retrospective observational study involving a small number of cases. Therefore, in order to improve the nutritional status and prognosis of patients with ESCC, prospective interventional trials are needed to clarify the optimal nutritional intervention during NAC. In addition, the evaluation of nutritional status may most likely have created some biases because of obstruction due to tumor-induced stenosis and the volume of consumed fluids, including any nutrients or parental nutrition, were not examined. These factors will affect the improvement of the nutritional status.

In conclusion, pre-Tx PNI is considered a prognostic factor irrespective of undergoing NAC. Patients in whom can PNI can be maintained or improved during NAC have a high probability of completing chemotherapy and obtaining a good prognosis. A nutritional intervention may be effective for patients with EC to maintain their nutritional status and improve prognosis.

\section{Conflicts of Interest}

The Authors have no conflicts of interest that should be disclosed in this research.

\section{Authors' Contributions}

Takao K, Konishi H, Fujiwara H and Shiozaki A designed the research; Shoda K, Kosuga T, Kubota T, Arita T, Morimura R, Murayama Y, Kuriu Y, Ikoma H, Nakanishi $\mathrm{M}$ and Okamoto $\mathrm{K}$ performed the research; Takao $\mathrm{K}$ and Konishi $\mathrm{H}$ performed the research and analyzed the data; Takao K, Konishi H, Fujiwara H and Otsuji E critically revised the manuscript for important intellectual content.

\section{References}

1 Bray F, Ferlay J, Soerjomataram I, Siegel RL, Torre LA and Jemal A: Global Cancer Statistics 2018: GLOBOCAN estimates of incidence and mortality worldwide for 36 cancers in 185 countries. CA Cancer J Clin 68: 394-424, 2018. PMID: 30207593. DOI: $10.3322 /$ caac. 21492
2 Sjoquist KM, Burmeister BH, Smithers BM, Zalcberg JR, Simes RJ, Barbour A and Gebski V: Survival after neoadjuvant chemotherapy or chemoradiotherapy for resectable oesophageal carcinoma: an updated meta-analysis. Lancet Oncol 12: 681-692, 2011. PMID: 21684205. DOI: 10.1016/S1470-2045(11)70142-5

3 Medical Research Council Oesophageal Cancer Working Group: Surgical resection with or without preoperative chemotherapy in oesophageal cancer: a randomised controlled trial. Lancet 359: 1727-1733, 2002. PMID: 12049861. DOI: 10.1016/S0140-6736(02)08651-8

4 Shapiro J, van Lanschot JJB, Hulshof MCCM, van Hagen P, van Berge Henegouwen MI, Wijnhoven BPL, van Laarhoven HWM, Nieuwenhuijzen GAP, Hospers GAP, Bonenkamp JJ, Cuesta MA, Blaisse RJB, Busch ORC, Ten Kate FJW, Creemers GM, Punt CJA, Plukker JTM, Verheul HMW, Bilgen EJS, van Dekken H, van der Sangen MJC, Rozema T, Biermann K, Beukema JC, Piet AHM, van Rij CM, Reinders JG, Tilanus HW, Steyerberg EW, van der Gaast A, CROSS study group: Neoadjuvant chemoradiotherapy plus surgery versus surgery alone for oesophageal or junctional cancer (CROSS): Long-term results of a randomised controlled trial. Lancet Oncol 16: 1090-1098, 2015. PMID: 26254683. DOI: 10.1016/S1470-2045(15)00040-6

5 Ando N, Kato H, Igaki H, Shinoda M, Ozawa S, Shimizu H, Nakamura T, Yabusaki H, Aoyama N, Kurita A, Ikeda K, Kanda T, Tsujinaka T, Nakamura $\mathrm{K}$ and Fukuda $\mathrm{H}$ : A randomized trial comparing postoperative adjuvant chemotherapy with cisplatin and 5-fluorouracil versus preoperative chemotherapy for localized advanced squamous cell carcinoma of the thoracic esophagus (JCOG9907). Ann Surg Oncol 19: 68-74, 2012. PMID: 21879261. DOI: 10.1245/s10434-011-2049-9

6 Hara H, Tahara M, Daiko H, Kato K, Igaki H, Kadowaki S, Tanaka Y, Hamamoto Y, Matsushita H, Nagase M and Hosoya Y: Phase II feasibility study of preoperative chemotherapy with docetaxel, cisplatin, and fluorouracil for esophageal squamous cell carcinoma. Cancer Sci 104: 1455-1460, 2013. PMID: 23991649. DOI: 10.1111/cas.12274

7 Watanabe M, Baba Y, Yoshida N, Ishimoto T, Nagai Y, Iwatsuki $\mathrm{M}$, Iwagami $\mathrm{S}$ and Baba $\mathrm{H}$ : Outcomes of preoperative chemotherapy with docetaxel, cisplatin, and 5-fluorouracil followed by esophagectomy in patients with resectable nodepositive esophageal cancer. Ann Surg Oncol 21: 2838-2844, 2014. PMID: 24715216. DOI: 10.1245/s10434-014-3684-8

8 Motoori M, Yano M, Yasuda T, Miyata H, Peng YF, Yamasaki M, Shiraishi O, Tanaka K, Ishikawa O, Shiozaki H and Doki Y: Relationship between immunological parameters and the severity of neutropenia and effect of enteral nutrition on immune status during neoadjuvant chemotherapy on patients with advanced esophageal cancer. Oncology 83: 91-100, 2012. PMID: 22777298. DOI: $10.1159 / 000339694$

9 Reisinger KW, Bosmans JW, Uittenbogaart M, Alsoumali A, Poeze M, Sosef MN and Derikx JP: Loss of skeletal muscle mass during neoadjuvant chemoradiotherapy predicts postoperative mortality in esophageal cancer surgery. Ann Surg Oncol 22: 44454452, 2015. PMID: 25893413. DOI: 10.1245/s10434-015-4558-4

10 Caccialanza R, Pedrazzoli P, Cereda E, Gavazzi C, Pinto C, Paccagnella A, Beretta GD, Nardi M, Laviano A and Zagonel V: Nutritional support in cancer patients: a position paper from the Italian Society of Medical Oncology (AIOM) and the Italian Society of Artificial Nutrition and Metabolism (SINPE). J Cancer 7: 131-135, 2016. PMID: 26819635. DOI: 10.7150/jca.13818 
11 Nozoe T, Kimura Y, Ishida M, Saeki H, Korenaga D and Sugimachi K: Correlation of pre-operative nutritional condition with post-operative complications in surgical treatment for oesophageal carcinoma. Eur J Surg Oncol 28: 396-400, 2002. PMID: 12099649.

12 Hu WH, Cajas-Monson LC, Eisenstein S, Parry L, Cosman B and Ramamoorthy S: Preoperative malnutrition assessments as predictors of postoperative mortality and morbidity in colorectal cancer: An analysis of ACS-NSQIP. Nutr J 14: 91, 2015. PMID: 26345703. DOI: 10.1186/s12937-015-0081-5

13 Ho JW, Wu AH, Lee MW, Lau SY, Lam PS, Lau WS, Kwok SS, Kwan RY, Lam CF, Tam CK and Lee SO: Malnutrition risk predicts surgical outcomes in patients undergoing gastrointestinal operations: Results of a prospective study. Clin Nutr 34: 679-684, 2015. PMID: 25175758. DOI: 10.1016/j.clnu.2014.07.012

14 Schwegler I, von Holzen A, Gutzwiller JP, Schlumpf R, Mühlebach S and Stanga Z: Nutritional risk is a clinical predictor of postoperative mortality and morbidity in surgery for colorectal cancer. Br J Surg 97: 92-97, 2010. PMID: 20013933. DOI: $10.1002 /$ bjs.6805

15 Onodera T, Goseki N and Kosaki G: Prognostic nutritional index in gastrointestinal surgery of malnourished cancer patients. Nihon Geka Gakkai Zasshi 85: 1001-1005, 1984. PMID: 6438478 .

16 Feng JF and Chen QX: Significance of the prognostic nutritional index in patients with esophageal squamous cell carcinoma. Ther Clin Risk Manag 10: 1-7, 2014. PMID: 24379675. DOI: 10.2147/TCRM.S56159

17 Migita K, Takayama T, Saeki K, Matsumoto S, Wakatsuki K, Enomoto K, Tanaka T, Ito M, Kurumatani N, Nakajima Y: The prognostic nutritional index predicts long-term outcomes of gastric cancer patients independent of tumor stage. Ann Surg Oncol 20: 2647-2654, 2013. PMID: 23463091. DOI: 10.1245/ s10434-013-2926-5

18 Sakurai K, Ohira M, Tamura T, Toyokawa T, Amano R, Kubo N, Tanaka H, Muguruma K, Yashiro M, Maeda K and Hirakawa $\mathrm{K}$ : Predictive potential of preoperative nutritional status in longterm outcome projections for patients with gastric cancer. Ann Surg Oncol 23: 525-533, 2016. PMID: 26307230. DOI: 10.1245/ s10434-015-4814-7

19 Mohri Y, Inoue Y, Tanaka K, Hiro J, Uchida K and Kusunoki M: Prognostic nutritional index predicts postoperative outcome in colorectal cancer. World J Surg 37: 2688-2692, 2013. PMID: 23884382. DOI: 10.1007/s00268-013-2156-9

20 Kanda M, Fujii T, Kodera Y, Nagai S, Takeda S and Nakao A: Nutritional predictors of postoperative outcome in pancreatic cancer. Br J Surg 98: 268-274, 2011. PMID: 20960457. DOI: 10.1002/bjs.7305

21 Japan Esophageal Society: Japanese Classification of Esophageal Cancer, 11th Edition: part II and and III: Esophagus 14: 37-65, 2017. PMID: 28111536. DOI: 10.1007/s 10388-016-0556-2

22 Clavien PA, Barkun J, de Oliveira ML, Vauthey JN, Dindo D, Schulick RD, de Santibañes E, Pekolj J, Slankamenac K, Bassi C, Graf R, Vonlanthen R, Padbury R, Cameron JL and Makuuchi $\mathrm{M}$ : The Clavien-Dindo classification of surgical complications: five-year experience. Ann Surg 250: 187-196, 2009. PMID: 19638912. DOI: 10.1097/SLA.0b013e3181b13ca2
23 National Institute of Health- Cancer Therapy Evaluation Program (2017) Common Terminology Criteria for Adverse Events (CTCAE) v5.0. Available at: https://ctep.cancer.gov/ protocoldevelopment/electronic_applications/docs/ctcae_v5_quic k_reference_5x7.pdf [Last accessed on July 16, 2020]

24 Yoshida N, Watanabe M, Baba Y, Ishimoto T, Iwagami S, Sakamoto Y, Miyamoto Y, Karashima R and Baba H: Influence of preoperative docetaxel, cisplatin, and 5-fluorouracil on the incidence of complications after esophagectomy for resectable advanced esophageal cancer. Dis Esophagus 27: 374-379, 2014. PMID: 23927456. DOI: 10.1111/dote.12117

25 Pinato DJ, North BV and Sharma R: A novel, externally validated inflammation-based prognostic algorithm in hepatocellular carcinoma: the prognostic nutritional index (PNI). Br J Cancer 106: 1439-1445, 2012. PMID: 22433965. DOI: 10.1038/bjc.2012.92

26 Yoshida N, Baba Y, Shigaki H, Harada K, Iwatsuki M, Kurashige J, Sakamoto Y, Miyamoto Y, Ishimoto T, Kosumi K, Tokunaga R, Imamura Y, Ida S, Hiyoshi Y, Watanabe M and Baba H: Preoperative nutritional assessment by controlling nutritional status (CONUT) is useful to estimate postoperative morbidity after esophagectomy for esophageal cancer. World J Surg 40: 1910-1917, 2016. PMID: 27220507. DOI: 10.1007/ s00268-016-3549-3

27 Di Fiore A, Lecleire S, Gangloff A, Rigal O, Benyoucef A, Blondin V, Sefrioui D, Quiesse M, Iwanicki-Caron I, Michel P and Di Fiore F: Impact of nutritional parameter variations during definitive chemoradiotherapy in locally advanced oesophageal cancer. Dig Liver Dis 46: 270-275, 2014. PMID: 24439424. DOI: $10.1016 /$ j.dld .2013 .10 .016

28 Fietkau R, Lewitzki V, Kuhnt T, Hölscher T, Hess CF, Berger B, Wiegel T, Rödel C, Niewald M, Hermann RM and Lubgan D: A disease-specific enteral nutrition formula improves nutritional status and functional performance in patients with head and neck and esophageal cancer undergoing chemoradiotherapy: results of a randomized, controlled, multicenter trial. Cancer 119: 33433353, 2013. PMID: 23765693. DOI: 10.1002/cncr.28197

29 Cools-Lartigue J, Jones D, Spicer J, Zourikian T, Rousseau M, Eckert E, Alcindor T, Vanhuyse M, Asselah J and Ferri LE: Management of dysphagia in esophageal adenocarcinoma patients undergoing neoadjuvant chemotherapy: Can invasive tube feeding be avoided? Ann Surg Oncol 22: 1858-1865, 2015. PMID: 25476030. DOI: 10.1245/s 10434-014-4270-9

30 Huddy JR, Huddy FMS, Markar SR and Tucker O: Nutritional optimization during neoadjuvant therapy prior to surgical resection of esophageal cancer-A narrative review. Dis Esophagus 31: 1-11, 2018. PMID: 29024949. DOI: 10.1093/ dote/dox 110
Received May 8, 2020

Revised July 15, 2020

Accepted July 16, 2020 